\title{
Alzheimer dementia's other victim: The spouse
}

Dan Gasby

Correspondence to

D. Gasby:

dan.gasby@

americanbrainfoundation.org

Neurology ${ }^{\circledR} 2017 ; 89: 1934-1937$
Editor's Note: The initial portion of this essay is an excerpt from the author's book (Before I Forget: Love, Hope, Help, and Acceptance in our Fight Against Alzheimer's. Copyright (C) 2016 by B. Smith, Dan Gasby, and Michael Shnayerson. Published by Harmony Books, an imprint of Penguin Random House LLC), reprinted with permission. Following this excerpt is an update from the events chronicled in the book.

In our 21-year marriage, I had acted not just as B.'s husband and best friend but as her business partner. I did the negotiating, got the book contracts and magazine deals and product endorsements. Now I had a new role: caregiver. I knew that hiring someone to help would make the most sense. I just didn't want to do it. I couldn't imagine a stranger in our Manhattan apartment, let alone our Sag Harbor house. I also felt no one could care better for B. than me. Which was true. But I hadn't anticipated how all-consuming that new job would be as the months wore on. All you caregivers out there-you know what I mean. It's hard.

For starters, I now did most of the house stuff: shopping and cooking, keeping the kitchen clean, and picking up after B. If I had meetings outside the apartment, I had to be sure B. would remember to eat while I was gone. Usually she didn't. A regular stop on my rounds was the B. Smith's on Restaurant Row. The restaurant was sputtering but still going, in part because B. could still stop by and talk up the tables. Unfortunately, the B. Smith's restaurant in Washington, DC, had closed earlier in 2013. Despite the good business we were doing, the rent was just too high for a location in Union Station, elegant as the station's restoration might be. As for our Sag Harbor site, it would last the summer of 2013, but I saw no way to justify keeping it through the next winter, a season when all Hamptons businesses struggle to stay alive. There, too, a high rent crimped our profits, and our biggest draw-B. herself - no longer felt able to talk up the summer crowd night after night. In all 3 restaurants, B. had been my full-time partner. She was at best a part-time partner now, and in a very limited way. It was like having one hand tied behind my back. Thank God we had all those B. Smith products in Bed
Bath of Beyond and a strong relationship with the company.

One of my largest frustrations had nothing to do with the business. B. was losing her intellectual curiosity. She couldn't get through a book. Movies and plays and the rest of the arts were simply a blur to her now. That was hard for me. I like a woman who's engaged with the world, who has opinions. If they're different from my opinions, all the better. A sharp debate creates tension, and tension creates sexual desire. When $B$. and I started dating, we could spend the whole evening debating the war with Iraq - the first President Bush's war-and let me tell you, the end of an evening like that was hot. I had to accept that that whole dynamic was pretty much gone, and not coming back. Which is not to say that sex was gone from our marriage. It was just at a very different vibe. At 64, B. was still a beautiful woman-a worldclass stunner, with that fabulous smile, perfect complexion, and gorgeous figure. You look at the picture on this book and tell me: Does she not look at least 15 years younger than her age? The desire I felt for her when we met was all-consuming; I still felt desire for her now, but on B.'s side the passion was gone. She loved me, but in a distracted way. She cuddled, but that was about it. The lover I knew was gone, replaced by a new, more muted version of the woman I had married. To be totally up front about it, I had my own issues. I was a veteran of prostate cancer. To the outside world, B. and I were as glamorous a couple as you could find. Privately we were struggling well before B. 's first memory lapse-before I even heard the word caregiver, much less knew what it involved. I got through the prostate surgery - the right way, which I won't elaborate on here; that's for another book-and I recovered, so as that scare eased, I was up for a little flirting from my wife, the kind that used to be as natural as breathing. We were still breathing, but flirting was just one of the many things we'd lost with Alzheimer's.

Instead, I had to do all the initiating. B. was sweet and gentle-affectionate, too. Just not responsive. Quiet-I guess that's the word that puts it best. Most of the time I resented the disease, but not always. Sometimes I resented B., too. Now that we had the diagnosis, I tried viewing the physical side of our marriage in a new way. As a person 
with Alzheimer's, B. lived more and more in the present. My challenge, as her husband and caregiver, was to immerse myself in the present tense with her. Not to expect her to remember what we'd planned for the day, or what we did the day before. Just to be there with her. And what in our day-to-day lives is more present tense than sex? In those moments of connection, all else is forgotten and falls away. How different, then, is making love when one of those 2 people has Alzheimer's? Before and after-yes. Very different. But not in the act itself.

B. couldn't join me in my world of past and future tense. But I could join her in her world, and make her happy there-and in so doing, make myself happy, too. The doctors and therapists who work with Alzheimer's caregivers have a phrase for this. Joining the journey. Your loved one with Alzheimer's is on a journey you cannot block or prevent. You can't even pull her aside for a while, trying to shake her into remembering what seems so obvious to you. All you can do is join the journey - to share with her each next moment of being, even as each next moment displaces the last. Making love, I've come to realize, is the ultimate in-themoment experience for a couple coping with Alzheimer's.

So is our time together after making love. That's the one time left when we still converse with real intimacy. It's when B.'s innermost feelings come out. It's when she'll say, "I know you love me, and I know you care, and I know I'm lucky to have you. "I feel that same depth of intimacy for her, even knowing the person beside me isn't quite the person she was. She's still B. to me-still beautiful, with all that same physical topography I know so well, and the same taste of her lips, and same sweet smell of her I've known so long I can't imagine not knowing it anymore.

Since we wrote Before I Forget together, B. has moved further along in her journey. Our journey. She won't be able to coauthor the next book with me.

It's a fact that when you see an iceberg, no matter how large, only one-fifth is seen above the surface. That which is unseen constitutes the bulk of its true mass. True also of what my fellow spousal caregivers and I reveal about the depth and breadth of what we confront and endure every minute of every day. Some days are worse than others. Hearing "I hate your guts!" from your spouse pierces your very being. Yes, I know it's not her, it's the disease, but I'm still human and still feel it. For the at-home caregiver, Alzheimer's is nothing short of domestic torture.

There are no diseases like Alzheimer's and dementia. They suck the caregiver through a mental and physical meat grinder. They take you down an emotional broken glass-filled drain and where you finally settle is a dark, closed-in, all-encompassing swamp of futility and despair. Some nights I have to hug her until the fire goes out and my spouse reemerges. I'm pretty good with words and expressing my feelings, but often now I'm mute, hollow, with no sky above or ground below me.

If Alzheimer's has taught me nothing else, it's that time doesn't belong to you as a caregiver and you triage everything, including family, friends, and business associates. Doing the right thing is many times lonely. But you stay because it's what you know your spouse would do for you. It's what B. would do for me.

Overnight. We've gotten a full-time home caretaker to help Mondays through Fridays, 9 to 5. I use that time to run our businesses. Weekends, our daughter, Dana, and I tag team. She and I now talk more with our eyes than our mouths around B.

But overnight, 5 to 9 , it's just me. Sometimes I must take my wife to the bathroom up to 4 times during the night. The overnight experiences set up a surreal morning.

My fellow caretakers will recognize this: no matter how much you love the person, it's hard to not feel as if they are terrorizing you. You are always on edge, sleeping with one eye open and trying to prevent a possible calamity from occurring. It's hell in slow motion. It feels as if you are under constant assault.

The patient moves at night like a ninja-silentalmost like they have pads on their feet. And you're awake watching them the way a hunter tracks its prey. You say nothing, hoping they will reverse course and lie back down. Sometimes they do! Whew! But most times they don't. Geez. But all the time you are on high alert.

Then, as dawn approaches, you're so tired, but nonetheless, on cue, the dance begins. The patient moves, you stay motionless in bed hoping it's just an aberrant twitch, but no-they're up. And, although the door is closed, you know it's only a matter of moments and they'll be out that door. Or the patient who kept both of us up all night is now the only one asleep.

Only fellow caretakers can really understand what morning is like when you live with someone who is journeying through Alzheimer's. There is no compromise. You cannot negotiate it better. You cannot pray it away. Hell, you don't have time to pray. You have to just be practical. Your mind is telling you, "Get out!"

When I grit my teeth and say "I'm tired of this! Why me?" I go to a place in my head and say these words: "You hate this, not her! You hate this, not her! You hate this, not her!" I keep repeating this in my head and say it quietly aloud until my anger and frustration passes.

Ready for morning time. Facebook asks: "What's on your mind?" 
My first thought is: I am thankful for having a healthy mind. Next, I'm thankful I recognize it's morning, and I know what month and day it is. From there on I just have an appreciation for all the little things in life we take for granted when we have good brain health.

It's a new day and life is life!

Not down with OPP: Other people's perspectives. After a long night, along will come someone who tells you how your spouse with Alzheimer's should look or dress. Sometimes those who know us best are the worst offenders. They know B. from her days as an international model and fashion magazine cover girl.

But what they don't know very much about is the disease or how it affects everyone in the family. The level of the lack of understanding of the spouse's reality is monumental. This is a devastating disease. It chews you up and makes you a different person. It never stops. Five minutes with the patient can feel like 5 days. You can never, ever let your guard down. It's unrelenting. People don't understand that, even with extra caregiver help, the bottom line is the patient has dementia. But, of course, you can't tie them up. You can't handcuff them. You must manage what is truly unmanageable.

Everyone who has an Alzheimer's patient in their life knows you can take their shoes and hope and pray that stops them from taking off or slows them down. It's a form of living hell being in the same space with someone who is not aware or in control of their very being. I've had to call the police department to pick up my wife after she walked away twice one morning. One day, it was 8 times.

I added locks to the doors in the house because my wife got to the point where she just wandered and opened anything. I had to add a door in front of all stairs because she'd walk up them and fall back. Or wander down the street at night while I slept.

And you don't feel like talking to people about this. You don't want people to give you advice constantly or ask you the same questions ad nauseam. Getting through the day is a roller coaster and you get tired of having to explain things. You get tired of hearing that doing your spouse's hair and makeup is all-important. It no longer is.

What people don't really comprehend about living day to day with someone experiencing the Alzheimer's journey is it is not "good day vs bad day." It is good minute vs bad minute. People need to know every other minute is another encounter causing the caretaker stress and sadness. Knowing it's only going to get worse is the only thing that's a certainty living with Alzheimer's. Spending the last random cognitive moments together is what's most important to me.

So, what does it ultimately mean for those who live with this hellish situation every single day? For me, it's best to not look back. I don't want to relive the past. Nostalgia is nice, but reality is your brother for better or worse-like a family member you don't like to deal with, but you must.

That is Alzheimer's up close and personal, and that's the minute-to-minute reality for those family members who must manage the patient's care.

Love. What is it like being in a really bad relationship with a really good person? It's called living with someone who has Alzheimer's! And there comes a point when you're living with a loved one with Alzheimer's, that your loved one becomes a different relative. For me, B. has become a sister. I love her, but it's different now. In many ways, deeper and more protective. Whatever I do, I will always do first for you, B.!

One day, as I was helping my wife bathe and get dressed, I just busted out laughing. She started laughing too. I didn't tell B. why I was laughing, but here it is: there was a time I was adept at getting a woman out of her clothes, but now I excel at getting one into her clothes!

There is no greater joy that I could ever receive then B.'s smile when she is happy or looks at me. When I must do something alone for the first time that we used to do together, I think of her smile. I've come to realize that after everything is said and done if I can just keep B. smiling I have done a good job.

Another day I was helping B. bathe and get dressed she looked me in the eye and said, "Please! Don't throw me away!" I will never, ever, forget her words and facial expression. Not only was her famous smile gone, her look was one of childlike fear. It stopped me in my tracks.

My lovely wife is experiencing the most god-awful thing a human being can intellectually confront. The realization that they are totally vulnerable. And they cannot control, hide, or confront it. I promised her I will not throw her away or discard her like the way you get rid of an old pair of shoes. To hear her say those words drained me. It angered me in a very sad way, as if I was sinking in quicksand or being wrapped up in a spider's web.

You see, Alzheimer's affects the caregiver in many instances much more than its victims. As I live and breathe, for as long as I do both, I want caretakers facing similar circumstances to know, I know your pain and stand with you. And for those who are fortunate enough to not be facing this unimaginable alternate universe, try thinking what life would be like if you did.

The future. I've been living in hell dealing with Alzheimer's and it's time to put the fire to good use. My head and heart are focused on the future. When you're battling something as overwhelming as Alzheimer's, and know its inevitability, you can either 
wallow in its certainty or pull yourself towards the future. I choose the future.

So, during the times that the home caregiver is with B., I work on marketing products that have a positive image, are brain healthy, are caretaker friendly, and point toward the future.

We're rolling out B. Smith Enterprises' new line of lifestyle products supporting health and Alzheimer's caregiving. The first offering is coffee by Gold Coffee's Parry Estates. A portion of sales proceeds from all the products will be earmarked to benefit brain health research.

Our home in East Hampton, New York, will include a B. Smith Brain Smart Style Lab that offers inspiration and insight for patients with Alzheimer's and their caregivers. It will serve as a brand integration idea incubator for B. Smith Brain Smart, brand partners, nonprofit organizations, and media.

Maplewood Senior Living is planning to open a projected $10 \mathrm{~B}$. Smith Advanced Lifestyle and Living branded properties around the country over the next 3-5 years. The company is recognized for its upscale senior living residences, offering a broad range of premier services, amenities, and care for its residents. For now, B. is at our home, but eventually, when the time comes, she will make her home in her namesake residence.

B. and I host and share our story in the documentary Too Soon to Forget: The Journey of Younger Onset Alzheimer's Disease by The Rush Alzheimer's Disease Center and TMK Productions, Inc. Please check www.bsmith.com for air dates and times.
This year I had the honor of becoming a board director of the American Brain Foundation. I join a team of amazing researchers and donors coming together to cure brain disease. Reflecting back, my experience has caused me to take a whole different approach to brain health and brain awareness in terms of the types of diseases that could affect human beings. This was the starting point for me to realize why, when I asked questions, so few people could talk to me about why we do the things we do. It all starts with the brain. It is with this perspective that I decided I wanted to understand not only why and how to make a difference with Alzheimer's, but also the $400+$ other brain-related diseases that affect 50 million Americans-approximately 1 in 6 people.

I move forward committed to B., Dana, and grace. Grace. It's a very powerful word. Among its many definitions, grace means to inspire virtuous impulses in human beings. It takes grace to deal with and live with someone with Alzheimer's. It takes grace to want to run far away from the daily grind of living with Alzheimer's and, nevertheless, remain steadfast in the face of unrelenting anguish and painful irrational days. Grace. It's a beautiful word. A sacred word one needs every minute of every day in confronting Alzheimer's and how it affects everyone it touches, especially the caretaker spouse.

\section{DISCLOSURE}

Dan Gasby is the business partner, husband, coauthor, and caretaker of B. Smith. Go to Neurology.org for full disclosures. 


\title{
Neurology
}

\begin{abstract}
Alzheimer dementia's other victim: The spouse
Dan Gasby

Neurology 2017;89;1934-1937 Published Online before print October 6, 2017

DOI 10.1212/WNL.0000000000004638
\end{abstract}

This information is current as of October 6, 2017

$\begin{array}{ll}\begin{array}{l}\text { Updated Information \& } \\ \text { Services }\end{array} & \begin{array}{l}\text { including high resolution figures, can be found at: } \\ \text { http://n.neurology.org/content/89/19/1934.full }\end{array} \\ \text { Permissions \& Licensing } & \begin{array}{l}\text { Information about reproducing this article in parts (figures,tables) or in } \\ \text { its entirety can be found online at: } \\ \text { http://www.neurology.org/about/about_the_journal\#permissions }\end{array} \\ & \begin{array}{l}\text { Information about ordering reprints can be found online: } \\ \text { http://n.neurology.org/subscribers/advertise }\end{array}\end{array}$

Neurology ${ }^{\circledR}$ is the official journal of the American Academy of Neurology. Published continuously since 1951, it is now a weekly with 48 issues per year. Copyright (O 2017 American Academy of Neurology. All rights reserved. Print ISSN: 0028-3878. Online ISSN: 1526-632X.

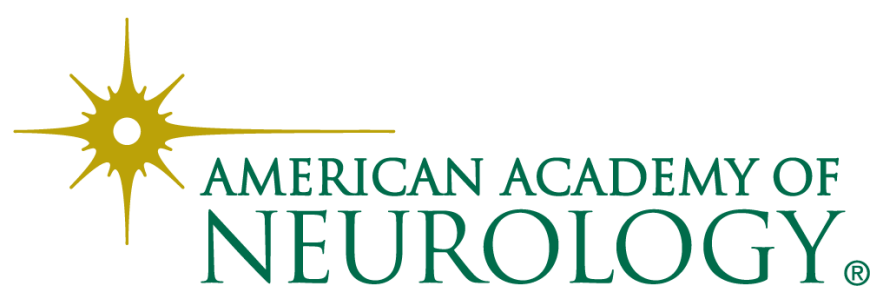

